\title{
The Road to War
}

The empires experienced the nineteenth century in different ways, and their experience was generally a bad one. The only empire to emerge in Central and Eastern Europe at that time - the German Empire - was also the only one that could regard the decades leading up to 1914 as a success.

Four powers figured on the map of Central and South-Eastern Europe in 1815: Prussia, Russia, Austria, and the Ottoman Empire. At the outbreak of war a century later, the northern borders appeared remarkably stable. Germany shared a border with Russia on Polish soil. Austria had evolved into Austria-Hungary, but its northern border had barely changed; only in the south, following the annexation of Bosnia-Herzegovina in 1908, did it extend much further than before. And indeed it was here, in the Balkans, that the changes were biggest, with the Ottoman Empire having lost its European foothold. The map of 1914 revealed six theoretically modern countries, i.e. selfstyled or would-be nation-states: Serbia, Montenegro, Greece, Bulgaria, Romania, and Albania, the last of these having come into existence a year earlier. Along the borders of these countries lived ethnic and religious minorities; territories on the other side were, for a variety of reasons, often the subject of competing claims and a host of mutual grievances. In Western Europe, the Balkan nation-states were regarded as backward; it is true that in terms of life expectancy, infant mortality, literacy, industrialization, and urbanization they lagged far behind the Netherlands or Denmark.

Of the great powers, only Russia had comparable problems. For centuries it had been the biggest country in the world, stretching from Łódź, the 'Manchester of the East', to the Pacific. It had also been a long-standing member of the exclusive family of empires. At the same time, Russia was struggling with problems that were unique to that group: a lack of compulsory schooling, the still unresolved question of land ownership, and industrialization limited to islands in the centre, south, and west of the country. In theory it was a military superpower, yet it had suffered defeat on its own territory at the hands of a Western expeditionary force (the Crimean War of 1853-1856). In 1904-1905, it became the first European - in racialized terms 'white' - power to be not so much defeated as utterly humiliated by an Asian - in racialized terms 'yellow' - power, i.e. the Japanese. Then, in 1905 and 1906, the country 
was shaken by revolution, when the edifice of autocracy, in other words, the power of the Czar, which was not limited by a constitution, began to crumble. Everyone knew that the problems began at the top - the head of state was accountable to no one and far from infallible - but a cancer of inertia, corruption, incompetence, and stupidity had spread throughout the entire state administration; after the catastrophic war with Japan and the defeat of the 1905 revolution, a new phase of energetic internal reforms got under way. For most, the favourable economic situation did not obscure the fact that the state remained inefficient, parliament was a façade, and social tensions were rising at a time when part of the rural population was being transformed into an urban, industrialized one. The issue of national minorities was likewise intensifying. In one relatively small part of Western Russia conflicts escalated around the hitherto privileged Baltic Germans, their neighbouring Latvians and Estonians, and the more distant Lithuanians, Jews, and Ukrainians: in the late nineteenth century and early twentieth century, it was not just in the Balkans that the national idea became a source of inspiration for pastors and priests, teachers and clerks, who up until then had been considered the docile backbone of empire; not to mention the old Polish problem, which was the price Russia had paid for moving its borders under the Partitions of Poland in the late eighteenth century and the terms of the Congress of Vienna in 1815.

The situation in Germany at the beginning of the twentieth century was somewhat different. Unlike Russia, the Second Reich combined the features of an empire and a nation-state. Germans accounted for over 90 per cent of its population. The differences between the inhabitants of East Prussia and Baden remained considerable, but people from Königsberg and Freiburg expressed these differences in the same language, and with recourse to a common literature and similar values. They were members of a nation that many considered a model of modernity. German universities were seen as the best on the continent, and the country boasted the most innovative industries, such as chemicals, as well as an excellent state and local administration. The army, which had always been regarded as Prussia's foremost achievement, had won all of its recent wars. The picture was not so rosy in the colonies, which generated a deficit and were third-rate, providing neither prestige nor satisfaction. Under such circumstances, imperial ambition was focused on the south-east rather than on overseas territories. The planned railway to Baghdad was considered the most important project, for it would enable German economic expansion into the Balkans and Ottoman Empire and onwards into the Middle East.

Germany and Russia were similar in two respects. First, both experienced a rising tide of nationalism in the late nineteenth century and early twentieth century. In Germany, nationalism was symbolized by the army, right-wing political parties, associations, and newspapers, and above all by Kaiser Wilhelm II. The long-time chancellor, Otto von Bismarck, whom the young 
Emperor ousted in 1890, was feared across Europe as a singularly devious and effective politician. Bismarck's successors lacked his charisma. Besides, the Emperor himself increasingly dabbled in foreign policy and loved to pose for photographs wearing a Pickelhaube (spiked helmet). Almost everywhere he went, Wilhelm aroused irritation as a posturing neurotic failure, offending all around him and provoking all manner of crises. In the history of modern Europe Wilhelm II will go down as one of the most incompetent monarchs with real power at their disposal. Nicholas II, who had ruled Russia since 1894, was the polar opposite of his cousin from Berlin in terms of temperament: his incompetence stemmed from his weakness. Russian nationalism thrived without any major contribution from the Czar.

Second, Russia and Germany were revered for their high culture, especially in the domains of literature and music, and foreigners were also attracted to Germany's outstanding universities. The superbly well-organized German working class was likewise considered worthy of imitation: Germany's Social Democratic Party (Sozialdemokratische Partei Deutschlands, SPD), which in the 1912 elections won almost 35 per cent of the vote, becoming the biggest parliamentary grouping, was supported by trade unions, educational and selfhelp organizations, and the most renowned left-wing intellectuals in Europe (which at that time meant in the world). But at the same time, the Reich, let alone Czarist autocracy, was a far cry from the soft power of Britain and France - the German lifestyle, from the aristocracy to the petite bourgeoisie, was not a model others wished to follow. During the Great War, knowledge of French remained the criterion by which cultured people - such as the mayor of an occupied city and its new commander - recognized each other.

Many were also repelled by the proverbial German arrogance and the equally proverbial Russian backwardness, which only reinforced the belief among German and Russian nationalists that their countries are disrespected and bullied by international public opinion.

The most complicated situation was that of Austria-Hungary. In 1867, the Habsburg monarchy was transformed into a dual monarchy with a single head of state (Franz Joseph ruled as King of Hungary and elsewhere as Emperor), foreign policy, army, and (in part) system of tariffs and finance. In the 48million-strong Habsburg monarchy, Austrian Germans and Hungarians accounted for less than half the population (44 per cent; the various Slavic peoples accounted for 47 per cent). In theory, other nationalities enjoyed rights that were guaranteed under the constitution, which allowed them to develop local government, education, and culture; in practice, the situation varied and was much worse in Hungary than in the Austrian part of the Empire, popularly known as Cisleithania, the peculiar jumble of Habsburg countries extending from Vorarlberg in the west, at the border with Switzerland, to today's western Ukraine. The parliaments in Vienna and Budapest were beset with problems: conflicts escalated, parliamentary sessions were suspended, and the government's 
accountability to the legislature became a fiction. The left demanded universal suffrage, which was introduced for the male population of Cisleithania in 1907. ${ }^{1}$ Hungary retained its existing electoral system that benefited both the ruling nationality and the propertied classes, which amounted to more or less the same thing. Austrian Germans in Bohemia and Moravia felt that they had been abandoned to the ever-more-powerful Czech national movement and, increasingly, looked to the thriving German Reich as a potential, if not ideal, guardian.

We are in no position to explain the distinctions between 'nationalities', ethnolinguistically defined, and 'nations' pretending to represent one general or particular nationality. Yet, East Central and South-Eastern Europe did not differ significantly from Ireland or Catalonia. The common denominator was the tendency towards secession from a former empire, in which those living at the centre cannot speak the language of those from the peripheries. Similarities abound in biographies of the aristocracy and the financial class: the former, universally suffered as a timeless and necessary evil around 1900; the latter, a foreign body. In the part of Europe under consideration here, both elites would be wiped out between 1918 and 1945, accounting for the distinctions between Barcelona, Belgrade, Budapest, and Dublin, but this falls outside the purview of this study.

To explain the peculiarities of the region, it might prove useful to turn to literary classics rarely revisited in the twenty-first century. The fragment in question concerns 'Kakania' - a garbling of the official name of the Habsburg monarchy after 1867, when it became the Austro-Hungarian Empire, 'kaiserlich und königlich' (the imperial and royal state). The first ' $\mathrm{k}$ ' thus represents Franz Joseph's role as the emperor of the aforementioned non-Hungarian lands; the other, his role as the king of Hungary. Robert Musil explains this in more detail in the following passage.

\section{KAKANIA}

There, in Kakania, that state since vanished that no one understood, in many ways an exemplary state, though unappreciated, there was a tempo too, but not too much tempo. Whenever one thought of that country from someplace abroad, the memory that hovered before one's eyes was white, wide, prosperous-looking roads dating from the era of foot marches and mail coaches, roads that criss-crossed the country in every direction like rivers of order, like ribbons of bright military twill, the paperwhite arm of the administration holding all the provinces in its embrace. And what provinces they were! Glaciers and sea, Karst limestone and Bohemian fields of grain, nights on the Adriatic chirping with restless cicadas, and Slovakian villages where the smoke rose from chimneys as from upturned nostrils while the village cowered between two small hills as if the earth had parted its lips to warm its child

${ }^{1}$ Pieter M. Judson, The Habsburg Empire. A New History, Cambridge 2016. 
between them. Of course cars rolled on these roads too, but not too many! The conquest of the air was being prepared here too, but not too intensively. A ship would now and then be sent off to South America or East Asia, but not too often. There was no ambition for world markets or world power. Here at the very centre of Europe, where the world's old axes crossed, words such as 'colony' and 'overseas' sounded like something quite untried and remote. There was some show of luxury, but by no means as in such overrefined ways as the French. People went in for sports, but not as fanatically as the English. Ruinous sums of money were spent on the army, but only just enough to secure its position as the second-weakest among the great powers. The capital, too, was somewhat smaller than all the other biggest cities of the world, but considerably bigger than a mere big city. And the country's administration was conducted in an enlightened, unobtrusive manner, with all sharp edges cautiously smoothed over, by the best bureaucracy in Europe, which could be faulted only in that it regarded genius, and any brilliant private initiative not backed by noble birth or official status, as insolent and presumptuous. But then who welcomes interference from unqualified outsiders? And in Kakania, at least, it would only happen that a genius would be regarded as a lout, but never was a mere lout taken - as happens elsewhere - for a genius.

All in all, how many amazing things might be said about this vanished Kakania! Everything and every person in it, for instance, bore the label of kaiserlich-königlich (Imperial-Royal) or kaiserlich und königlich (Imperial and Royal), abbreviated as ' $k$. k.' or 'k.\&k.', but to be sure which institutions and persons were to be designated by 'k.k.' and which by 'k.\&k.' required the mastery of a secret science. On paper it was called the Austro-Hungarian Monarchy, but in conversation it was called Austria, a name solemnly abjured officially while stubbornly retained emotionally, just to show that feelings are quite as important as constitutional law and that regulations are one thing but real life is something else entirely. Liberal in its constitution, it was administered clerically. The government was clerical, but everyday life was liberal. All citizens were equal before the law, but not everyone was a citizen. There was a Parliament, which asserted its freedom so forcefully that it was usually kept shut; there was also an Emergency Powers Act that enabled the government to get along without Parliament, but then, when everyone had happily settled for absolutism, the Crown decreed that it was time to go back to parliamentary rule. The country was full of such goings-on, among them the sort of nationalist movements that rightly attracted so much attention in Europe and are so thoroughly misunderstood today. They were so violent that they jammed the machinery of government and brought it to a dead stop several times a year, but in the intervals and during the deadlocks people got along perfectly well and acted as if nothing had happened. And in fact, nothing really had happened. It was only that everyone's natural resentment of everyone else's efforts to get ahead, a resentment we all feel nowadays, had crystallized earlier in Kakania, where it can be said to have assumed the form of a sublimated ceremonial rite, which could have had a great future had its development not been cut prematurely short by a catastrophe. 
For it was not only the resentment of one's fellow-citizens that had become intensified there into a strong sense of community; even the lack of faith in oneself and one's own fate took on the character of a deep self-certainty. In this country one acted - sometimes to the highest degree of passion and its consequences differently from the way one thought, or one thought differently from the way one acted. Uninformed observers have mistaken this for charm, or even for a weakness in what they thought to be the Austrian character. But they were wrong; it is always wrong to explain what happens in a country by the character of its inhabitants. For the inhabitant of a country has at least nine characters: a professional, a national, a civic, a class, a geographical, a sexual, a conscious, an unconscious, and possibly even a private character to boot. He unites them in himself, but they dissolve him, so that he is really nothing more than a small basin hollowed out by these many streamlets that trickle into it and drain out of it again, to join other such rills in filling some other basin. Which is why every inhabitant of the earth also has a tenth character that is nothing else than the passive fantasy of spaces yet unfilled. This permits a person all but one thing: to take seriously what his at least nine other characters do and what happens to them; in other words, it prevents precisely what should be his true fulfilment. This interior space - admittedly hard to describe - is of a different shade and shape in Italy from what it is in England, because everything that stands out in relief against it is of a different shade and shape; and yet it is in both places the same: an empty, invisible space, with reality standing inside it like a child's toy town deserted by the imagination.

Insofar as this can become visible to all eyes it had happened in Kakania, making Kakania, unbeknownst to the world, the most progressive state of all; a state just barely able to go along with itself. One enjoyed a negative freedom there, always with a sense of insufficient grounds for one's own existence, and lapped around by the great fantasy of all that had not happened or at least not yet happened irrevocably as by the breath of those oceans from which mankind had once emerged.

Events that might be regarded as momentous elsewhere were here introduced with a casual 'Es ist passiert ...' - a peculiar form of 'it happened' unknown elsewhere in German or any other language, whose breath could transform facts and blows of fate into something as light as thistledown or thought. Perhaps, despite so much that can be said against it, Kakania was, after all, a country for geniuses; which is probably what brought it to its ruin. ${ }^{2}$

The various lands of the Austro-Hungarian Empire were developing at an uneven pace. Both capitals were among the most modern European cities. Budapest acquired its first metro line in 1896; Vienna followed two years later. Bohemia and Moravia could easily rival the highly developed regions of Western Europe, while Galicia and Bukovina were closer to their eastern and south-eastern neighbours than they were to modernity.

2 Robert Musil, The Man without Qualities, vol. 1, translated by Sophie Wilkins and Burton Pike, New York, NY, 1995, pp. 28-31. 
Yet sentiment, loyalty to the monarchy, and national consciousness had little to do with this asynchronous development. Austria-Hungary was a country in which everyone was more or less dissatisfied; its citizens increasingly began to think in national terms - they did not wish to live in a community with people who spoke a different language. Hannah Arendt would later write that 'tribal nationalism always insists that its own people is surrounded by "a world of enemies", "one against all", that a fundamental difference exists between this people and all others, ${ }^{3}$ but for now the ethnicization of relations within the monarchy was generally not based on violence, and thus the state persisted. Its symbol was the Emperor, who from 1867 was also King of Hungary. Virtually no one remembered a monarch other than Franz Joseph, who had ruled since 1848. The belief in a just ruler - one who rules from afar, high above the quarrels and disputes of politicians and students - gave people hope: the monarchy had for decades ensured peace and a tranquillity of sorts, so would it not survive the latest turmoil engulfing European politics in the early twentieth century?

The empires would not be empires were they not seeking to gain advantage over others. In this race Russia had the lowest chances of success, for despite enormous progress it remained the weakest of the imperial powers. It had suffered defeat in the Far East, and in Central Asia it no longer presented a threat to Great Britain. Russia's weakest opponent was the Ottoman Empire. Petersburg actively supported the decomposition of the Ottoman Empire's European foothold and entered into alliances with the Balkan states. Of greatest importance were its close ties with Bulgaria and Serbia, the latter having switched from the Austro-Hungarian to the Russian camp in 1903. Serbia became the mainstay of Russia's Balkan policy, according to which Russia was the protector of the South Slavs and the Orthodox Church.

Petersburg's alliance with Belgrade was a huge irritation for the Habsburg monarchy. First, Serbia's role as an advocate of South Slav unification threatened the southern borders of Austria-Hungary, inhabited mainly by Croats, Slovenes, Bosnians, and Serbs. Second, Belgrade's alliance with Petersburg had its extension in the Entente, in other words, in Russia's diplomatic agreements with both France and Britain. The Austrian military saw Russia's relationship with Serbia as an existential threat to the Habsburg monarchy and pushed for a quick resolution to the problem: from 1906, the influential Chief of the General Staff, Franz Conrad von Hötzendorf, argued for a preventive war against Serbia. Historians estimate that in 1913 alone, von Hötzendorf proposed to attack Belgrade on twenty-five separate occasions. In May 1914 he reiterated his proposal, which - for now - the Emperor and the politicians once again ignored.

${ }^{3}$ Hannah Arendt, The Origins of Totalitarianism, Houghton Mifflin Harcourt, Orlando, FL 2008, p. 227. 
THE FRIEDJUNG AFFAIR

When in 1908 Austria-Hungary decided to annex Bosnia-Herzegovina, Europe stood on the brink of war. Although the region had been occupied by the Habsburg Monarchy since 1878, once Serbia had entered the Russian sphere of influence the decision to formally incorporate the province took on a political meaning. Russia regarded the annexation as a hostile act that violated its interests in the Balkans; it eventually stood down, but the two monarchies would never again be on friendly terms. Russia's influence in Belgrade increased, however, and within a few years this led to the creation of an anti-Ottoman coalition.

Given that the Austro-Hungarian Ministry of Finance had for decades pursued a sovereign policy in Bosnia-Herzegovina, the formal annexation of the province need not have taken place in such dramatic circumstances. Yet a deterioration in the situation lay very much in the interests of the Imperial Foreign Minister, Count Alois Lexa von Aehrenthal, the main instigator of the so-called Bosnian crisis. Aehrenthal was strongly in favour of an aggressive policy that befitted a superpower. To his surprise, Western public opinion did not respond at all well to the annexation, which prompted Aehrenthal to try to justify the action retrospectively.

His idea seemed perfect, but ultimately it embarrassed the Austro-Hungarian authorities. In 1909, dozens of Serb politicians from Croatia stood before a court on charges of treason. They were accused of being Serbian agents who were conspiring to harm the monarchy. The purpose of the trial was not merely to justify Aehrenthal's aggressive policy; it was also in the interests of the Hungarians, who wanted to put an end to Croatian autonomy within the Kingdom of Hungary. The problem was that the charge of treason rested on very flimsy evidence. Robert W. Seton-Watson, a British specialist on Central and Eastern Europe and the Balkans, observed the trial in Zagreb from the public gallery. In his report for the Morning Post, Seton-Watson wrote: 'The whole trial is a travesty of justice, inspired and controlled by what to English ideas is a despotic government. ${ }^{4}$ In a private letter to Henry Wickham Steed, another British expert and future editor of The Times, Seton-Watson added that the judges appointed to conduct the show trial looked as though they themselves had just been released from a penal colony. Since this impression was shared by many of the others present, Aehrenthal decided that it was time for a new batch of incriminating evidence.

It was precisely at this moment that Heinrich Friedjung entered the political arena. Born in Moravia to Jewish parents, Friedjung was a historian, one of the pioneers of modern political history, as well as a German nationalist. His ambitions went further, however: he wanted to become the leader of the Austrian Germans. He had worked with Aehrenthal for several years and shared his political views. In the autumn of 1909, Friedjung published an article in the Neue Freie Presse, a liberal daily, in which he cited documents allegedly given to him by the Austro-Hungarian Embassy in Belgrade. The documents ostensibly proved that Serbia was preparing

${ }^{4}$ Quoted in Hugh Seton-Watson and Christopher Seton-Watson, The Making of a New Europe. R. W. Seton-Watson and the Last Years of Austria-Hungary, Seattle, WA 1981, p. 69. 
an armed attack on the Habsburg monarchy and that it was financing politicians in the Serbo-Croat coalition. It soon transpired, however, that the documents were forgeries, and at the end of the year a group of Croatian politicians sued Friedjung for libel. Tomáš Garrigue Masaryk spoke about the affair in the Viennese parliament (the Reichsrat), denouncing the Foreign Minister for his dirty tricks.

The whole affair was a humiliation both for Friedjung and for the AustroHungarian authorities, but its psychological effects proved far more serious. First, the rule of law, with which Austria-Hungary was rightly associated, had been undermined by the personal imperial ambitions of a handful of politicians. Second, the hysterical reaction of the authorities towards Serbian, Croatian, and Slovenian politicians who had hitherto been completely loyal to the monarchy did in fact push them into the arms of Serbia. Third, the Friedjung affair called into question the ability of Austria-Hungary to soothe relations between the feuding peoples of Central and Eastern Europe and the Balkans.

The permanent conflict between Vienna and Petersburg over Serbia had its counterpart in the north. Galicia was governed by the Poles. The vast majority of them felt attached to the monarchy, but they were also building national institutions, lending assistance to émigrés from the Kingdom of Poland, and encouraging young people to join paramilitary organizations. Somewhat different was the situation of the Ukrainians, who at that time were generally referred to as 'Ruthenians' by Poles and as 'Little Russians' by Russians. Both the Poles and the Russians consistently denied Ukrainians the right to call themselves a nation, but they, too, were creating their own associations and institutions, and were mostly pro-Habsburg, with an active pro-Russian minority (the 'Russophiles'). The difference between the politically active Poles and Ukrainians was that the former had power, elites, and a clear sense of national identity, whereas the latter organized themselves at the grassroots level and had few elites to speak of; some Ukrainian intellectuals believed in the creation of a Ukrainian nation allied with the monarchy, while others treated the Ruthenians as part of a greater Russia. Petersburg accused Vienna of supporting the Poles and the 'national' Ukrainians; Vienna accused Petersburg of inciting 'Russophilia'. There was seemingly no end to political trials, not to mention bitter polemics in the press.

Serbia was incomparably more important than Galicia. From 1903, the European press wrote about the situation on Austria-Hungary's southern border almost constantly; it was not only Conrad von Hötzendorf who perceived the seeds of a future war there. What was clear was that a localized conflict between Vienna and Belgrade was just one of many possible scenarios - and by far the least dangerous one. Austria-Hungary had been in an alliance with Germany since 1879, and after Italy joined in 1882 it was known 
as the Triple Alliance. But Italy was an uncertain partner and could not be relied upon. France and Great Britain resolved their colonial disputes in 1904 with the signing of the Entente Cordiale. In 1907, the nascent alliance was joined by Russia - Serbia's protector - which had hitherto been allied with France alone. Following its defeat in the Far East in 1904-1905, there was one thing Russia certainly could not afford: humiliation in the eyes of Europe.

Each of the powers prepared for war in different ways. Russia, aware of its limitations, invested proportionally the most in its armed forces (30 per cent of the national budget) in the years leading up to 1914. Over six years, Russia's military spending increased by 40 per cent and its naval budget tripled, surpassing Germany's; by 1917, Russia's army will be three times bigger than that of its western neighbour.

But none of this was enough: the army did not teach the peasants how to write, nor did it build an efficient arms industry or eliminate the structural backwardness of the Czarist state.

It had long been known that railways were crucial to modern warfare. In October 1850, during the Austro-Prussian crisis, the Habsburg monarchy was able to transport 75,000 soldiers and 8,000 horses to its northern border in less than four weeks. Prussia backed down. Sixteen years later, Prussia needed only three weeks to move almost 200,000 soldiers and 55,000 horses to the front. This time Austria was the loser. And four years after that, the French were unable to make proper use of their otherwise modern railway network: on the twenty-third day of mobilization they had 270,000 battle-ready soldiers, whereas Prussia mobilized 460,000 in the same amount of time. All the general staffs studied the wars of 1866 and 1870 and they all reached the same conclusion: that a future war could not be won without a dense and efficient railway network.

In subsequent decades the Reich built railways to enhance its power. Prussia became the largest employer in Germany; on the eve of war, it employed approximately 700,000 railway workers. Russia had the lowest-density rail network. This difference was most stark on Russia's border with its two neighbours, Austria-Hungary and Germany: whereas in the Kingdom of Poland there were 25 metres of track per capita, in Galicia the figure was twice as high, and in the eastern provinces of the Reich it was six times higher. ${ }^{5}$

Austria-Hungary's military preparedness was likewise far below the level that its generals had for years been demanding. While the monarchy believed that the railway network on the borders with Serbia and Russia was probably sufficient, it was definitely not prepared for one thing: a rapid campaign with maximum effort on two fronts simultaneously. Nevertheless, the monarchy knew that this would be the worst-case scenario if Russia came to Serbia's

5 Andrzej Chwalba, Historia Polski 1795-1918, Cracow 2000, p. 65. 
defence. In that event, Vienna would be forced into close cooperation with Berlin as soon as military operations began, for it could not wage a war on two fronts simultaneously if Germany did not engage some of the Russian forces from the outset. And it was only the Reich that was properly prepared for war in the East. However, the head of the Supreme Army Command (Oberste Heeresleitung, OHL), Helmuth von Moltke, feared that these were the last moments when Germany still had the advantage. A preventive war had to be fought now or never, insisted Moltke to the Foreign Minister in May 1914. 'Later' might simply mean 'too late'. Since the Russian armaments programme had already begun, argued Moltke, by 1917 Germany would lose its trump cards in the East; the very trump cards that currently allowed it to treat Russia as a second-rate opponent.

To this day, the decision-makers in uniform are adjudged to have completely failed. Indeed, many of them promised politicians and public opinion a short and victorious war. Whether this was due more to a lack of imagination than to a lack of competence is hard to determine. In the military academies, future officers of the general staffs were taught war planning using nineteenthcentury models; it was thus difficult to blame them for thinking in terms of the Crimean War and the Franco-Prussian war of 1870. Fortresses, bristling ever more densely with artillery, were constantly being upgraded and in 1914 would prove as useless in the East as in the West. On the future northern section of the Eastern Front, the Russians built huge complexes of fortifications in Osowiec, Modlin (Novogeorgievsk), Dęblin (Ivangorod), and Kaunas. The Germans massively fortified the fields on the outskirts of Königsberg, while the Austrians built an impregnable fortress in Przemyśl (Premissel) and protected Cracow with a ring of forts and bunkers.

Many a general was troubled not just by the millions of tons of cement and steel needed to build the fortresses. The army now possessed fantastic means of killing the enemy, the latest innovation being the heavy machine gun. But enemies had exactly the same equipment. The continental powers could draw upon vast numbers of reservists, but each state introduced compulsory military service; in other words, millions were set against millions. Finally, everyone had powerful allies, and indeed that was the problem: everyone.

Their doubts notwithstanding, the generals devised plans for a future war. They all knew that rail transportation would play a key role, but they had limited influence over investment in the railways. To mitigate this, they demanded more money for everything and the extension of compulsory military service. In the most recent major conflict, the Russo-Japanese war of 1904-1905, the Russians had run out of artillery ammunition (besides everything else) and had been forced to import it, since local factories had been unable to increase production in line with demand. General staffs thus assumed that artillery ammunition would be used on an unprecedented scale and accordingly built huge warehouses to store it. Austria-Hungary and Russia 
kept much of their munitions in their fortresses. When, in the summer of 1915, the Germans captured Kaunas and Novogeorgievsk with relative ease, 3,000 artillery pieces and 2 million shells fell into their hands. In the previous year, the Russian armaments industry manufactured only 285 artillery guns and 660,000 shells. ${ }^{6}$

In Germany, despite opposition from the SPD (the largest parliamentary party), the government managed to force through a bill in the summer of 1913 that increased the size of the peacetime army from 754,000 to 890,000 men, or 1.3 per cent of the population. This confirmed foreign observers in their belief that the threat of 'Prussian militarism' was indeed hanging over Europe. In fact, in France, the proportion of men under arms was 2.3 per cent (in Russia and Austria-Hungary it hovered around $0.8-0.85$ per cent). France and Russia spent roughly 5 per cent of GDP on the military, whereas Germany spent less than 4 per cent and Austria-Hungary just over 3 per cent.

None of the plans laid by the imperial general staffs survived the first weeks of fighting in August 1914. This was also because no general or field marshal would publicly admit that he shared the misgivings of the leading light of the profession, Helmuth von Moltke. The legendary architect of Prussia's fast, victorious wars with Austria and France appeared in the Reichstag for the last time in May 1890. His words astounded the deputies:

The age of cabinet war is behind us - all we have now is people's war, and any prudent government will hesitate to bring about a war of this nature, with all its incalculable consequences. [...] Gentlemen, if the war which has been hanging over our heads like the Sword of Damocles for more than a decade - if this war were to break out, then no one will be able to foresee how long it will last or how it will end. The greatest powers in Europe, armed as never before, will confront each other in battle. [...] Gentlemen, it may be a seven years' war or a thirty years' war - and woe to him who sets Europe alight, who puts the first fuse to the powder keg. ${ }^{7}$

The ninety-year-old elder statesman was gladly forgiven this flight of fancy as it was so clearly not part of the Zeitgeist. Age takes its toll - it was said - and von Moltke's time had passed. Others would not have got away with such overt defeatism. Von Moltke's nephew and namesake, the aforementioned head of the Supreme Army Command in 1914, who was younger by two generations, privately harboured similar concerns. But in that summer, neither he nor his colleagues in other European capitals would dare to challenge the widespread view that the war would be short and victorious.

${ }^{6}$ Peter Gatrell, 'Poor Russia, Poor Show: Mobilising a Backward Economy for War, 1914-1917', in The Economics of World War I, ed. Stephen Broadberry and Mark Harrison, Cambridge 2005, pp. 235-275, here p. 242.

7 Stenographische Berichte über die Verhandlungen des Deutschen Reichstags, 1890/91, vol. 114, p. 76 n, 14 May 1890. 
It was only minorities who challenged this view. The biggest among them were the socialist parties united in the Second International, and this now forgotten tradition is worthy of some attention. The socialists were afraid of war: millions of mobilized workers, killing their comrades in enemy uniform just so that the capitalists sitting in their offices could make a handsome profit, was a nightmarish vision. At their congresses they often debated the issue. Radicals proposed a preventive, international general strike in the armaments industries; the majority believed that this was impractical and pointless because an international general strike would surely break out across the world as soon as the spectre of war had begun to materialize.

In July 1914, all the Western socialist deputies joined the parliamentary majorities in their own countries and voted for war. Not for the first or last time, the Marxist dream of international proletarian solidarity would be crushed by nationalism.

An altogether different kind of pacifism was represented by Baroness Bertha von Suttner, née Countess Kinsky, a well-known and widely read writer on the human condition and winner of the 1905 Nobel Prize. Her most important work, Die Waffen Nieder (Lay Down Your Arms!), was published in 1889 and became a bestseller in the German-speaking world. Suttner's book was translated into many languages. The novel's protagonist is a woman who loses her loved ones during the endless conflicts between the European powers (beginning with the war of 1859 between Austria, Piedmont, and France, and ending with the Franco-Prussian War of 1870-1871). Suttner's commitment to the struggle for peace saw her participate in various international peace conferences, including the First Hague Peace Conference of 1899. She certainly contributed more to the pacifist cause than the initiator of the Hague Conference, Czar Nicholas II of Russia.

The Warsaw banker Jan (Ivan, Jean de, Johann von) Gotlib Bloch arrived at the Hague by a different route. In 1893 he began to publish a series of articles in Polish entitled Future War and Its Economic Consequences. Over the next five years these essays evolved into a five-volume work called The War of the Future in Its Technical, Economic and Political Relations, published in 1898-1900 in Polish, Russian, French, German, and Dutch, and in an abridged version in English as Is War Now Impossible? ${ }^{8}$ Bloch was a kind of pseudo-scientist who can more accurately be described as a hobbyist; unlike his rivals, he was wealthy enough to have a team of researchers work on his amateur project. He treated war from the standpoint of an enlightened European who was concerned about the fate of the Old Continent. For Bloch, the return of

${ }^{8}$ Jan G. Bloch, Przyszła wojna pod względem technicznym, politycznym i ekonomicznym, Warsaw 1900. A new edition of extensive sections of the work, compiled by Grzegorz P. Bąbiak, was published by the Polish Institute of International Affairs in 2005. The translations are generally restricted to the most important sections. 
violence to international relations was an absolute evil - the most fundamental threat to civilization in the fin de siècle. His rather dull disquisition, overburdened with statistics and numbering 3,000 pages, showed that the European powers had already accumulated enough firepower to annihilate the entire continent. In support of his argument Bloch offered a comprehensive analysis of the unprecedented growth in the means of destruction. From this perspective the fact that a future war would quickly ruin the European economy seemed rather trivial, although for Bloch's fellow bankers it would soon become of paramount importance. In the month of disgrace, July 1914, their warnings about the impending apocalypse would fall on deaf ears.

Bloch viewed the world from a Warsaw perspective. He lived in a vibrant city that was fast approaching one million inhabitants. Its early modern fortifications had long since been demolished, although, as in many other cities in the region, new ones had been erected. However, such fortifications became obsolete the moment they were completed and hampered urban development. Indeed, it was hard to find a better illustration of the futility of the arms race. ${ }^{9}$ At the same time, Bloch lived in a country where, as in most parts of Europe, military service had been mandatory for decades. He was one of very few to draw the logical conclusion that a war between the empires would not only cause the death of hundreds of thousands of young men but would also present a challenge that no society or economy can meet. A future war would end in defeat for all its participants: advances in technology would turn battlefields into slaughterhouses from which no modern state could emerge victorious. Each state could commit an unimaginable number of people and resources to a supposedly final battle. The war would ruin both the winners and the losers in equal measure - materially, physically, morally. Hence, the categories of 'winner' and 'loser' were a thing of the past.

At the turn of the century, Bloch became the leading advocate of a small minority among the haute bourgeoisie (we should not hesitate to use this term as he was one of the richest men in Russia) which recognized that a future war between the great powers would signal catastrophe for all its participants: the probability of victory was vanishingly small and the costs utterly disproportionate. The military planners of the day rejected the theories of this Varsovian amateur in disgust. They knew better. What riled them most about Bloch was that The War of the Future was not just about war: lurking in the background of this weighty tome was the fundamental question of whether a civilized society should entrust its fate to military men. And it is precisely this question that generals, of whatever time, place, and uniform, cannot bear.

9 The Warsaw Fortress was abandoned in 1909, yet reconstruction commenced in 1913. In the 1890s Bloch believed that the city was part of the Russian system of fortifications on the Vistula and was profoundly troubled by that thought. 
THE OFFENSIVE DOCTRINE

In the first months of the Great War, quite unexpectedly, one of the most frequently quoted German writers on both sides of the front was Friedrich von Bernhardi. Although this cavalry general and military theorist was not the most elegant of writers, he responded perfectly to the exigencies of the moment. Germany and its allies drew from Bernhardi's works the comforting belief that they were certain to emerge victorious from the unfolding conflict. Their opponents regarded Bernhardi as a symbol of German chauvinism and militarism, and not without reason. Here, for example, is what the author believed to be the impact of the arms race on the society of the pre-war Reich: 'We have accustomed ourselves to looking upon our armaments as a heavy burden, forgetting thereby that the army is the well from which our people constantly draws new strength, self-sacrificing spirit, and patriotism. ${ }^{10}$ Despite the severe reprimands he meted out to German public opinion, which he believed was overly pacifist, Bernhardi was optimistic about the outcome of what he regarded as an inevitable future European conflict. His hopes for victory rested on an unshakeable belief in the superior war morale of the Germans. The most important factor in this victory would be initiative (or, as he put it, 'the principle of action').

A reader who takes the trouble to distil Bernhardi's views from the poetic efflorescence of Greater-German chauvinism will have to concede that he expressed not just the views of German strategists but also the beliefs prevalent in all the general staffs of Europe. In very simple terms these can be summarized as the superiority of spirit over matter and the superiority of attack over defence. Bernhardi's optimism about Germany's chances of victory was based on the otherwise sound observation that, hitherto, these principles had been most effectively implemented during the Prussian campaign against France in 1870-1871. In addition, the period leading up to the Great War seemed to provide new arguments to the advocates of the offensive doctrine. In the years 1904-1905, European military officers had their eyes fixed on the Russo-Japanese war. The Russian commander in Manchuria, General Alexei Kuropatkin, was a proponent of the defensive doctrine. In contrast, the Japanese trained by German instructors - embraced the idea of a permanent offensive. Although the Russian defeat had many different causes, observers focused precisely on the difference in strategy. Indeed, Kuropatkin, looking to excuse his own incompetence, also invoked one of these magical formulas:

In the late war [...] our moral strength was less than that of the Japanese; and it was this inferiority, rather than mistakes in generalship, that caused our defeats. [...] The lack of martial spirit, of moral exaltation, and of heroic impulse, affected particularly our stubbornness in battle. In many cases we did not have sufficient resolution to conquer such antagonists as the Japanese. ${ }^{11}$

${ }^{10}$ Friedrich von Bernhardi, On War of To-Day [Vom heutigen Kriege], authorized translation by Karl von Donat, New York, NY 1914, vol. 1, p. 12.

11 A[lexei] Kuropatkin, The Russian Army and the Japanese War, vol. 2, London 1909, p. 80. 
Military analysts completely ignored the cost of the Japanese victory. In fact, the Japanese losses were much higher than those of the defeated Russians. Both sides already had modern artillery and machine guns. A mass of Japanese infantry perished in relentless attacks using bayonets, especially during the assault on Port Arthur. Their fanaticism aroused the admiration of European general staffs, who were not too troubled by the Japanese losses. After all, the future war was going to be swift anyway. Impressed by Manchuria, the French adopted the so-called Grandmaison doctrine in 1911, which assumed l'attaque à outrance (attack to excess).The preferred tactic was to push forces as close as possible to enemy lines and then launch a massive assault using bayonets. Even heavy losses were less important than the supposedly beneficial effect such an attack would have on troop morale.

In 1914, almost without exception, the armies that faced each other were focused on attack at the level of both strategy and tactics. The only lesson drawn from the war of 1904-1905 was that, for an attack to be effective, it had to be massive. The cost of this doctrine proved appallingly high.

Our final note before we turn to the Great War in the East will become clearer in this context.

The 1912-1916 period witnessed manoeuvre warfare no less bloody than in the trenches of Verdun or the Somme. Official dispatches often mentioned the Habsburg archdukes, the nearest relatives of Nicholas II of Russia, and the members of ruling dynasties from various parts of the Reich. Meanwhile, generals on both sides of the Russian front were typical members of the noblesse de robe, whom the aristocracy viewed as nobodies, and who owed their careers not to noble birth, but to individual talents. August von Mackensen (1849-1945) received a noble rank only in 1889; in the Great War, he proved to be the finest German commander in the East, with a combat trail beginning in East Prussia in 1914 (where he lost a battle, but gave the German units time to regroup), through the Gorlice offensive of 1915, the capture of Belgrade in December of that year, and culminating in the defeat of Romania in 1916. Alexei Brusilov (1853-1926), the only Russian general who managed to shake up the Southwest Front, was one of the few generals to be respected, perhaps even supported, by Russian public opinion. Still, he could not take up a seat either in the Duma or in the State Council as, under Russian law (which was quite consistent on this point), serving officers were forbidden from doing so. Brusilov's political career ended before it had even started. Conrad von Hötzendorf (1852-1925) may have been born a nobleman, but earned the title of count only in July 1918, as a palliative following his dismissal as commander of the Italian Front (where he had just suffered another defeat). ${ }^{12}$ We might also add to this cohort Marshal Paul von

12 Wolfram Dornik, Des Kaisers Falke. Wirken und Nach-Wirken von Franz Conrad von Hötzendorf, Innsbruck 2013, p. 175. 
Hindenburg (1847-1934), the Poznań-born legend of the German army, retired due to advanced age, but returned to active duty in the summer of 1914. ${ }^{13}$ The resulting image is of a group of old men (with an average age in 1915 of 65 years); professional soldiers, probably ailing, locked in a world of map pennants, and removed from the reality faced by soldiers who could be their grandsons, but whom they were now about to send out to die.

\section{July 1914}

The empires' month of disgrace began with the assassination of Franz Ferdinand. For four weeks, cabinets deliberated and foreign ministries churned out memos at the same rate as the general staffs. In the monarchies, meetings were held with the Emperor. Here and there, influential bankers, industrialists, editors-in-chief, and occasionally the chairmen of parliamentary clubs appeared in the background. But they all played a lesser role in this game, because it was not about money but about prestige and Great Power status. Politicians outside the government and the publishers of mass-circulation newspapers likewise had little to say, but they did count because they could mobilize public opinion. And without public support, neither a monarchy nor a republic would venture into war.

In each country, all the major decisions were taken by a group of a dozen or perhaps several dozen men, who were predominantly middleaged (although elderly men quite often made an appearance too). This group was greatly depleted on account of the season: July was the month when gentlemen would take their annual leave, usually with their wives. Wilhelm II spent these crucial weeks on a yacht. His Minister of War, General Erich von Falkenhayn, was relaxing on an island in the North Sea. Helmuth von Moltke the Younger arrived in the spa town of Carlsbad for his annual holiday on the day Franz Ferdinand was assassinated. The death of the Archduke apparently made little impression on him. He cut short his holiday only after learning of the Austro-Hungarian ultimatum to Serbia and returned to Berlin on 25 July. Germany was no exception: the Serbian Chief of the General Staff, Radomir Putnik, almost missed the war entirely. He spent the summer of 1914 in a sanatorium in Bad Gleichenberg in the enemy state of Austria. On his way home he was arrested in Budapest by the Hungarian gendarmerie, before being released at the personal request of Franz Joseph; it appears that the Emperor could not countenance the arrest of an enemy who had come to the monarchy as a fellow bather.

${ }^{13}$ Wolfram Pyta, Hindenburg. Herrschaft zwischen Hohenzollern und Hitler, Munich 2007. 
The experiences of other decision-makers were not as thrilling as Putnik's. Slowly they returned to their offices at the end of the month. Few of them cared that share prices on the stock exchanges were beginning to nose-dive. Bloch was dead, and the economic catastrophe he predicted was beginning to be felt by his fellow financiers; soon it would spread to petty savers. Although the newspapers were agitated about the threat of war, military men were not especially in evidence. Politicians believed in their promise that the war could be won quickly, and public opinion believed it all the more. On the whole, decision-makers were badly informed. Their principal sources of information were press dispatches and diplomatic reports, in other words, sources that usually described yesterday's news. The French delegation, which was headed by the President and Prime Minister, returned from its trip to Russia by boat. The journey took six days. Germany was adept at jamming communications; the exchange of messages in the crucial days of the crisis took even longer than normal. The telephone still played a secondary role and was mainly used for local calls. Secure communications were unknown at the beginning of the twentieth century, but in all probability they would not have changed much.

Few players in this game felt they had anything to win. All Great Britain could do was to protect its global position, the foundations of which lay outside of Europe anyway. London would only be forced to intervene when provoked by Germany, which for a good twenty years had been questioning Britain's unique position. The construction by the Reich of a powerful navy had long been a bone of contention - nothing did more to undermine relations between the two countries than Wilhelm's idiotic plan to rival Britain on the seas. During the war the German fleet waged one major battle against the British, which it half-won, yet it was still unable to break out of its ports on the North Sea and the Baltic. The German revolution of 1918 began in the country's naval bases.

The Reich was indeed the only power that questioned the European order. Historians have written many thousands of pages on this subject and have tried to reconcile two contradictory points of view: on the one hand, the Reich had for years been developing at a much faster pace than Great Britain. In 1913 there was no doubt that, if peace held, Germany's position as the most economically powerful country would strengthen with each passing year. Germany did not have the possibility to expand its territory, but it didn't want to anyway: in the west this could be done only at the expense of Belgium, the Netherlands, or France, which was unthinkable; in the east, only at the expense of Russia, which in practice would mean incorporating millions of Poles into the Reich. This was not an especially appealing prospect. 'What could we possibly want from Russia?', asked the liberal Prince Heinrich zu Schoenaich-Carolath during a parliamentary 
debate in May 1914: 'Perhaps Warsaw and the Poles? I thought we'd had enough of them.' ${ }^{14}$

On the other hand, regardless of the Emperor's pugnacious personality, it was the Reich that engaged most often and most willingly in sabre rattling. Various attempts have been made to explain this behaviour: Germany as a 'belated nation', which did not experience unification until 1871; the tradition of Prussian militarism; the interests of big business (a particularly nonsensical claim given that industrialists and bankers, even if they were unfamiliar with the works of Bloch, knew full well that peace served their interests much better than war did); the desire to resolve apparently growing internal tensions at a single stroke; and nationalism. All these factors were important but they do not explain why, in July 1914, Germany heightened its belligerent and aggressive stance much more than the other European powers. Public opinion - excluding the social democrats, who were reluctant to endorse pro-war sentiment - believed that Germany was surrounded by a hostile coalition of states. Besieged-fortress syndrome is a tremendously destructive force: German students, who volunteered for the army even more eagerly than their British counterparts, clearly believed that they would be fighting to defend their fatherland against the barbarous East and materialistic West, that they were the defenders of the only true European culture.

The British and French, and the Russians, likewise believed in their own moral superiority: the former were defending Europe as a whole; the latter were protecting their brother-Slavs against Prussian militarism and German arrogance. The French were also hoping to avenge the defeat of 1870 . They felt wellprepared. Without the joyful excitement of people on the streets, before editorial offices, and in churches, and without the support of socialist parties urging their constituents to stand shoulder to shoulder with the defenders of the fatherland, it is hard to imagine the disgraceful month of July 1914. At the same time, we know that, although millions of peasants - who accounted for the vast majority of the population of Central and South-Eastern Europe - allowed themselves to be conscripted into the army and obediently marched to the front, their faces revealed very little enthusiasm. In parts of Russia mobilization was accompanied by disturbances and unrest, often associated with the mass consumption of alcohol. Binge drinking was a ritual practised by every new conscript, but on this occasion the young men were being sent not to the barracks but to the front. For the time being all this seemed unimportant, as did the fact that the only parties of the Socialist International to remain faithful to the principles proclaimed by European socialists and to openly oppose the war were the Russian Bolsheviks and Mensheviks and their comrades in the Serbian parliament.

The image of feverish crowds on the streets demanding war remained in the memory of West European societies. This created a feedback loop: the masses

${ }^{14}$ Quoted in Włodzimierz Borodziej, Geschichte Polens im 20. Jahrhundert, Munich 2010, p. 77. 
were easy to incite, while the politicians and journalists, who were calling for a reckoning with the enemy, saw the result of their efforts as further evidence that they reflected the views and interests of the people. The unity of the nation in the face of danger, moral superiority over the enemy, the defence of a just cause, and faith in a rapid victory - all this conspired to make the summer of 1914 seem beautiful and sublime.

Yet the decisions were taken in offices, and not at rallies. The story still evokes astonishment today - rarely in history have the European elites been so lacking in reason. On 28 June, a young Serb citizen of the Austro-Hungarian Empire managed, somewhat fortuitously, to shoot the heir to the throne, the Archduke Franz Ferdinand and his wife.

FRANZ FERDINAND D'ESTE

Franz Ferdinand had long been the most controversial successor to the Habsburg throne in Vienna. A nephew of Franz Joseph, he was known for his arrogance and dogmatism and had a talent for alienating people. He became the heir-presumptive in 1896 after the death of his father, the Emperor's younger brother. Franz Ferdinand underwent a decent military education and had experience as an army officer. He appreciated modern military technology and lent his support to likeminded staff officers. From his many travels to exotic places he brought back hunting trophies in bulk quantities. At the family's seat in Konopiště, Bohemia, one can still see the remnants of his vast collection of game kills, which is said to have numbered at least a quarter of a million. Against the will of the Viennese court, Franz Ferdinand married the beautiful countess Sophie Chotek. As a person of lower rank (everything is relative ...), she was not invited to official ceremonies. The couple's children were excluded from the succession and thus could not inherit the throne. Franz Ferdinand loathed the court and most of the political establishment.

But appearances were deceptive, at least in part. Franz Ferdinand was more than just an arrogant archduke typical of every ruling family. He believed that the state was in a critical condition and required radical change. The enemies of the monarchy were 'Jews, freemasons, socialists, and Hungarians'. ${ }^{15} \mathrm{He}$ felt that the Hungarians, in particular, were an utter disgrace to the Habsburg Empire as they were ruthless and adept in taking advantage of their (theoretically weaker) position in the system of dual power - a system in which neither member could exist without the other. Franz Ferdinand also had an original solution to the problem of the South Slavs, that is, Serbia (an enemy since 1903), Bosnia-Herzegovina (annexed in 1908), the Kingdom of Croatia (which belonged to Hungary), and the Slovenes (who inhabited Cisleithania). Serbia had proclaimed the unification of fraternal nations under its own leadership. But Franz Ferdinand pushed for a different solution: the creation of a kingdom of South Slavs as the third element of the Habsburg monarchy. Hungarians dismissed the idea outright, Austrian Germans were

15 Quoted in Dornik, Des Kaisers Falke, p. 67. 
ambivalent, and Poles and Czechs also rejected this version of trialism because they aspired to a different kind of tripartite monarchy: one in which they were the third pillar. The heir-presumptive concocted his plan in the beautiful Belvedere Palace in Vienna, ignoring the angry murmurings within the monarchy's political class. In Europe, Franz Ferdinand was seen as the leader of the Viennese 'hawks', but this was a mistaken view because he opposed the idea of a preventive war. Although he generally supported the dashing Conrad von Hötzendorf - the two men were united in their belief that the army was the mainstay of the monarchy - he argued constantly with the Chief of the General Staff: for the heir to the throne, military conflict seemed altogether too risky.

Franz Ferdinand ignored all the warnings about his planned visit to Sarajevo. We shall never know whether the person who died on 28 June 1914 was a political visionary or a charlatan.

Europe was outraged. People were aware that, without the long-standing conflict between Austria and Serbia, the assassination would not have happened. In the view of many, the conspiracy trail led to Belgrade. There was no hard evidence for this, but who needed evidence when Vienna had received European sympathy, solidarity, and compassion on a plate, and now had the perfect excuse to finally settle scores with the 'swineherds' south of the border?

The Austrian military urged war. It easily secured the unconditional support of Berlin, where von Hötzendorf's colleague, the head of the Supreme Army Command von Moltke, had also been waiting patiently for the opportunity to strike. Who cared that the war plans of Germany and Austria-Hungary were contradictory? Berlin wanted to throw seven-eighths of its army against the French and along the way violate the neutrality of Luxembourg and Belgium. Only after defeating its western neighbour did it intend to shift the bulk of its ground forces to the Russian front. The Habsburg monarchy planned to punish Serbia in spectacular fashion, through humiliation and international disgrace. War with Russia did not seem particularly enticing given weak German support in the initial phase, but von Hötzendorf was a risk-taker and regarded the Russians (not to mention the Serbs) with disdain. During the Berlin talks one week after the assassination in Sarajevo, Germany pledged its full support to AustriaHungary in the event of an attack on Serbia.

In Vienna a complicated decision-making process was under way. The Hungarian Prime Minister, Count István Tisza, feared attacking Serbia. His arguments were similar to those advanced by Prince Heinrich zu SchoenaichCarolath, only that the Serbs took the place of the Poles: why did the monarchy need yet more Slavs? But after a week of discussions he came around to the idea. History can be cruel: the only Central European politician to successfully 
oppose the impending catastrophe for several days was gunned down in October 1918 by assassins who held him responsible for starting the war.

After Tisza's capitulation, Vienna waited. The President and Prime Minister of France visited Russia. Vienna felt it would be a mistake to do anything so long as potential adversaries could confer on the spot rather than by telegraph or through diplomatic channels. On 23 July the French delegation left St Petersburg. That same day Vienna handed Belgrade an ultimatum. It was carefully constructed in such a way that no sovereign state could possibly accept it. One of the demands was that the monarchy's officials should participate in the investigations of the Serbian authorities into the Sarajevo assassination and into the suppression of movements that sought to undermine the territorial integrity of Austria-Hungary; in both cases this meant allowing foreign officials to act against Serb citizens within the territory of Serbia. Vienna intended to wait no longer than forty-eight hours for an answer.

On 25 July Belgrade acceded to almost all of the Austrians' demands with the exception of the two mentioned above, as these were clearly contrary to the principle of sovereignty. Serbia's deft response, which promised to cease antiHabsburg propaganda and punish the assassins, astonished even Wilhelm II. Somewhat crestfallen, the Emperor wrote that, since Belgrade had allowed itself to be publicly humiliated, there was no reason to start a war. Vienna seized the opportunity regardless - after all, the Serbs had failed to meet two of their demands - and on 28 July declared war.

Berlin and Vienna had received numerous warnings during the month: that Russia would not countenance another loss of face and would spring to Serbia's defence; that the Franco-Russian Alliance would trigger an automatic response; that Italy could not be counted on; and that Great Britain would in all likelihood not remain passive. But it was all for nothing. On 30 July Russia announced general mobilization, followed a day later by Austria-Hungary and Belgium. On 1 August Germany and France followed suit. Germany declared war on Russia and on the following day occupied Luxembourg and presented an ultimatum to Belgium. On 3 August the Reich declared war on France and received an ultimatum from Great Britain. A day later Germany attacked Belgium, prompting Britain to declare war on Germany. On 6 August Austria-Hungary declared war on Russia. On the following day the first troops of the British Expeditionary Force disembarked in France. Austro-Hungarian troops attacked Serbia on 12 August, and three days later the Russians entered East Prussia. Montenegro had already allied itself with Serbia; the Ottoman Empire joined the war in October as an ally of the Central Powers - the war thus engulfed all of Central and Eastern Europe. In the Balkans, three states - Bulgaria, Romania, and Greece - for now remained neutral. 
The central and eastern parts of the continent were sucked into the war by megalomaniac empires. This applies least of all to Germany and the Germans the Reich, uniquely, was at once an empire and a modern nation-state, and its politicians and military were used to thinking in both imperial and national terms. Yet, despite this, they were no less megalomaniac than the other empires, for they convinced themselves and their fellow countrymen that Germany was surrounded by enemies, and that only a massive pre-emptive strike to the east and to the west could destroy the thickening cordon before it was too late. Austria-Hungary essentially wanted just to punish Serbia, and later, as war fever intensified, to annihilate it. Russia went to war for the sole purpose of recovering its tarnished Great Power status. The empires sent their citizens to the front, although none harboured the traditional war aim of securing regional hegemony, annexing a disputed province, or installing a puppet on a foreign throne. Christopher Clark, the author of one of the most prominent recent books about the summer of 1914, quite reasonably refers to the imperial policy-makers as 'sleepwalkers'. ${ }^{16}$

A few weeks after the July domino effect, which had already managed to destroy the European order, the Russian Prime Minister Sergei Witte complained that the war was pure madness: what could Russia expect to gain from it? More territory, perhaps? Surely the lands of His Imperial Highness were already sufficiently large ... ${ }^{17}$

If, in the summer of 1914, any imperial politician had known what lay in store for his country, he would certainly not have done his bit to seal the fate of nineteenth-century Europe, that is, the world of empires.

16 Christopher Clark, The Sleepwalkers. How Europe Went to War in 1914, London 2012.

17 Alexander V. Prusin, Nationalizing a Borderland. War, Ethnicity and Anti-Jewish Violence in East Galicia, 1914-1920, Tuscaloosa, AL 2005, p. 13. 